Southern Methodist University

SMU Scholar

Fondren Library Research

Fondren Library

2013

\title{
Abraham Lincoln, Management Guru! Lessons for Library Leadership on Resilience, True Grit and Bouncing Forward.
}

Gillian M. McCombs

Southern Methodist University, gmccombs@mail.smu.edu

Follow this and additional works at: https://scholar.smu.edu/libraries_cul_research

Part of the Library and Information Science Commons

\section{Recommended Citation}

McCombs, Gillian M., "Abraham Lincoln, Management Guru! Lessons for Library Leadership on Resilience, True Grit and Bouncing Forward." (2013). Fondren Library Research. 3.

https://scholar.smu.edu/libraries_cul_research/3

This document is brought to you for free and open access by the Fondren Library at SMU Scholar. It has been accepted for inclusion in Fondren Library Research by an authorized administrator of SMU Scholar. For more information, please visit http://digitalrepository.smu.edu. 


\section{Abraham Lincoln, Management Guru! Lessons for Library Leadership on Resilience, True Grit and Bouncing Forward.}

\section{Gillian M. McCombs, Dean and Director, Central University Libraries, Southern Methodist University}

This has been a big year for Abraham Lincoln. Museums, libraries and re-enactors all over the nation continued to celebrate the Civil War sesquicentennial. Stephen Spielberg made a movie simply entitled Lincoln, Daniel Day Lewis won the Best Actor Academy Award for his portrayal of Lincoln in that movie, and a recent article by Nancy Koehn in the New York Times entitled "Lincoln's School of Management," discussed his leadership qualities and drew a Twitter of comments hailing Lincoln as a prototype management guru. ${ }^{1}$

As Koehn's article points out, many CEOs and Presidents have drawn inspiration from President Lincoln. But what are the lessons we lesser mortals might gain from studying him? Very few of us are destined to be challenged by the larger issues of the country as Lincoln was - slavery, property rights, homesteading, and of course, the Civil War. Koehn's article and other Lincoln-inspired writings offer a slew of reasons why Lincoln's life and work offer meaningful lessons for today's leaders and managers. Take a look at Spielberg's Lincoln for instance - a movie tells a story. It is not offered to the public as a factual record of events. Artistic license is a given. And yet, some of the most stirring parts of the movie come from hearing Lincoln's own words - his speeches, diaries, letters (and those of others), ably documented by Doris Kearns Goodwin and other prominent historians. It makes us long - not for a demagogue (we have seen and continue to see, plenty of those) - but a true leader who passionately articulates her causes, outlines her vision and moves us, the listeners, to a higher plane.

Clearly, this is one lesson to be learned - a leader needs to be able to articulately and passionately outline a vision - whether it be of the $21^{\text {st }}$ century library, intellectual freedom, open access or more equitable staff salaries - and to thereby inspire the group to buy into this vision and take appropriate 
action. But the movie also draws our attention to the fact that one of Lincoln's greatest qualities, throughout his progress to the White House, eventual issuing of the Emancipation Proclamation and the passing of the $13^{\text {th }}$ Amendment, was resilience. He did not give up, ever, staying in for the long haul which turned out to be shorter than anyone could have imagined. Goodwin describes him as "More accustomed to relying upon himself to shape events, he took the greatest control of the process leading up to the nomination, displaying a fierce ambition, an exceptional political acumen, and a wide range of emotional strengths, forged in the crucible of personal hardship, that took his unsuspecting rivals by surprise." $^{2}$

The importance of resilience, or the ability to rebound from the hardships of life, is emphasized several times in Koehn's article. Her comments reflect a large body of work over the years on the superiority of resilience or grit over intellectual brilliance. Paul Tough, in his 2012 monograph How Children Succeed: Grit, Curiosity, and the Hidden Power of Character, documents new childhood research studies which show that this quality is much underestimated in creating scenarios for how children (and by extension adults) succeed. ${ }^{3}$ The children who survive adversity better are not necessarily those who are smartest, but those who do not give up, are resilient, and use a variety of internal coping mechanisms to achieve their goals. Perhaps the numerous familiar adages such as 'A smooth sea never made a skilled mariner' (English proverb) or 'Difficulties strengthen the mind as well as labor does the body' (Seneca) have a nugget of truth.

Elle Allison, in her work with educators, specifically focused on this quality - "In the face of change and crisis, the resource we need most is our resilience." ${ }^{4}$ She describes resilience as "a personal quality that predisposes individuals to bounce back in the face of loss. Resilient leaders, however, do more than bounce back - they bounce forward. With speed and elegance, resilient leaders take action that responds to new and ever-changing realities, even as they maintain the essential operations of the 
organizations they lead." 5 She outlines a numbers of ways that organizational leaders can tell if they are becoming less resilient and offers a short list of personal practices and coaching opportunities. Her work parallels that done by Jackson and Watkin who created a resilience inventory. ${ }^{6}$ They believe "it is not simply what happens to us but how we respond to what happens to us, that has the greatest effect on the trajectory of our personal and working lives." ${ }^{\prime 7}$ Diane Coutu uses the 9/11 terrorist attack to generate a discussion on why some people bounce back from tragedy while others do not. ${ }^{8}$ This finding has also been documented several times in the research literature on Holocaust survivors. ${ }^{9,10}$

Interesting, you say, but what relevance does this have for the readers of this journal? Why am I writing a column on this topic in a journal devoted to research in our profession? Because I believe that too often we promote libraries like mom and apple pie, presuming on the perception of libraries as a common good to secure our success. We are not always skilled at or willing to do the politicking needed, to strategize on how to attain our goals - we often just stand around, wring our hands and bemoan our fate. One of the most memorable quotations from Spielberg's movie is spoken by Pennsylvania Congressman Thaddeus Stevens, who averred that the most liberating constitutional amendment in history had been "passed by corruption, aided and abetted by the purest man in America." ${ }^{11}$ Lincoln used all the means at his disposal, including utilizing what Paul Tough has called "a calibrated meanness." ${ }^{12}$ I believe that we library leaders need to toughen up the skills we have at our disposal in order to take advantage of the incredible opportunity we have in the $21^{\text {st }}$ century - to position libraries and our services to be fundamental for the success of our institutions. Our business, the business of connecting people to the resources they need for research, pleasure, and the daily round of living in a complex world, is the lens through which almost everything is seen these days, whether we approve of it or not. From Twitter to Pinterest, The Daily Beast to MOOCs, if you are not Linkedln or Tumblring you might just as well be using a stylus on a waxed tablet or reading from cuneiform stones. 
In October, 2012, in this same guest editorial spot, James Matarazzo and Toby Pearlstein invited us to rethink the vision of our library and information science schools. ${ }^{13}$ They see a growing distance between educating and training information professionals to serve $21^{\text {st }}$ century needs, and a research focus that is not additive or grounded in improving the lives of our users. We need to change, and where better to start than at the top? So, start asking the question, are you resilient? How do you react when the going gets tough? How many of your staff exhibit this quality? How can you tell if someone has it? How can you hire for it? Witold Rybczynsky notes these same qualities of having the long-headed view and being resilient in his book $A$ Clearing in the Distance : Frederick Law Olmsted and America in the Nineteenth Century, in referring to Frederick Law Olmsted, America's greatest landscape architect. ${ }^{14}$ Olmsted, like Lincoln, planned in terms of decades or even longer - "He looks far ahead, and his plans and methods are sometimes mysterious ... he is only long-headed ..." 15

How do we begin? First, we need to realize that we, the employers, have to start looking at how we rate and assess the many resumes that come across our desk. Perhaps a varied background is more advantageous and not evidence of a 'can't hold a job, doesn't know what he/she wants to be' prospect. These candidates might, instead, possess a breadth of experience and more openness to new ways of thinking and ideas than those who present with a traditional academic resume. We need to expand our horizons in our professional reading. Take the Harvard Business Review, for instance, there are many articles on the softer skills needed to successfully run an organization. Read the NYT Business section columns, such as Corner Office (exploring management insights with non-traditional CEOs of small, agile, innovative companies), or The Boss, where a CEO tells his story (hearkening back to Lincoln and his love of telling stories.) What is your story? How do you engage your public? I now live in Texas and learning 
to tell my story has been an important part of creating authenticity and articulating my vision for the SMU libraries.

We all have our personal heroes or champions in our profession, people who made us sit up and wish that we had had the courage to take that kind of action or undertake a particular long term campaign. Two for me have been Lynn Sutton, library Dean at Wake Forest University, who successfully championed faculty status for her librarians and an enhanced salary structure for all staff through a succession of Provosts; and Judith Nadler, Director and University Librarian at the University of Chicago, whose total commitment and chutzpah were responsible for situating the brilliantly light-filled Mansueto Library Reading Room on top of a subterranean robotic book bunker holding 3.5M volumes deep underground on the central University of Chicago campus. Michael Moore, the left-wing political film maker, writer and provocateur, dedicated his book Dude, Where's my Country to librarian Ann Sparanese (among others), "one simple act, a voice was saved, are there a million more of her to save us all?" ${ }^{16}$ If you remember, when Moore's book Stupid White Men; ... And Other Sorry Excuses for the State of the Nation! was being pulled from the presses by Harper Collins because it was deemed too critical of President Bush right after 9/11, Sparanese, a librarian from Englewood, N.J., (dubbed a "cyberspace Paul Revere" in ALA's Cognotes) created a campaign that resulted in hundreds of librarians writing to the publisher. ${ }^{17}$ As a result, the book went into numerous printings and became an instant best-seller. Moore commented later, “I really didn't realize the librarians were, you know, such a dangerous group. ... They are subversive ... They're like plotting the revolution, man. I wouldn't mess with them. You know, they've had their budgets cut. They're paid nothing. Books are falling apart ..." ${ }^{18}$

By digging into the culture of our varied institutions, we can figure out how to position ourselves to be a force for the future. Yes, our budgets are being cut, our staff are being laid off or not replaced and our deep print collections are under siege. This is a time when higher education as a whole is under national 
scrutiny - from Congress to parents, people are asking the question - "Is higher education worth what we are paying? Oh, and by the way, why are we paying so much?" College tuitions soar each year, advancing far in excess of the inflation rate. The overall inflation rate of a college education since 1986 increased $115.06 \%$, on the other hand, during the same time, tuition increased $498.31 \%$, according to Bureau of Labor statistics. ${ }^{19}$ We library leaders are being called upon to articulate a vision that positions us as part of the solution not part of the problem. This is absolutely the time when we and our staff need to call on that font of resilience, articulate our passionate vision for the future and bounce forward. The inspirations are many, but let us also leave more for those who come after us. Four score years and seven from now, will people still be proud they knew us and didn't mess with us? Will we have left our mark on our communities and our institutions?

\section{Notes}

1. Nancy F. Koehn, "Lincoln's School of Management," in The New York Times, Jan. 27, 2013 http://www.nytimes.com/2013/01/27/business/abraham-lincoln-as-managementguru.html?pagewanted=all\&_r=0

2. Doris Kearns Goodwin, Team of Rivals: The Political Genius of Abraham Lincoln. (New York, N.Y.: Simon \& Schuster, 2005), xvi.

3. Paul Tough, How Children Succeed: Grit, Curiosity, and the Hidden Power of Character. (New York, N.Y.: Houghton Mifflin Harcourt, 2012.)

4. Elle Allison, "The Resilient Leader," in Educational Leadership 69, 4 (2011) 79-82. http://www.ascd.org/publications/educational-leadership/dec11/vol69/num04/The-ResilientLeader.aspx (accessed April 12, 2013)

5. Ibid.

6. Rachel Jackson \& Chris Watkin, "The Resilience Inventory: Seven Essential Skills for Overcoming Life's Obstacles and Determining Happiness" in Selection \& Development Review, 20, 6 (2004), http://org-portal.org/fileadmin/media/legacy/the_resilience_inventory.pdf (accessed March 31, 2013)

7. Ibid.

8. Diane Coutu, "How Resilience Works" in Harvard Business Review, May 2002, 80, 5, 46-51.

9. Daniel Goleman, "Holocaust Survivors Had Skills to Prosper," in The New York Times October 6, 1992. http://www.nytimes.com/1992/10/06/science/holocaust-survivors-had-skills-toprosper.html?pagewanted=all\&src=pm (accessed March 31, 2013)

10. Efrat Barel, "Surviving the Holocaust: A Meta-Analysis of the Long-Term Sequelae of Genocide," in Psychological Bulletin, 2010, 136, 5. 677-698. 
http://depts.washington.edu/bcpt/docs/Barel\%20et\%20al,\%20Surviving\%20the\%20Holocaust\% 20Psych\%20Bull\%202010\%20\%20136\%205\%20677\%20698.pdf (accessed March 31, 2013)

11. Milton Meltzer, Thaddeus Stevens and the Fight for Negro Rights, (N.Y.: Crowell, 1967), 159.

12. Paul Tough, How Children Succeed: Grit, Curiosity, and the Hidden Power of Character, 119.

13. James M. Matarazzo and Toby Pearlstein, "Schools of Library and Information Science: Some Thoughts on Vision to Purpose," portal: Libraries and the Academy, 12, 4, (2012): 315-353.

14. Witold Rybczynsky, A Clearing in the Distance : Frederick Law Olmsted and America in the Nineteenth Century, (New York, N.Y.: Scribner, 1999)

15. Ibid.

16. Michael Moore, Dude, Where's my Country (New York, N.Y. : Warner Books, 2003.)

17. As cited in Indiana University Department of Library Science and Information News, June 2002. http://ils.indiana.edu/news/story.php?story_id=443 (accessed March 31, 2013.)

18. Michael Moore, BuzzFlash interview, 13 March, 2002, http://www.buzzflash.com/interviews/2002/03/Michael_Moore_031302.html (accessed March 31, 2013.)

19. The Smart Student Guide to Financial Aid, http://www.finaid.org/calculators/costprojector.phtml and Bureau of Labor Statistics http://www.bls.gov/cpi/ (accessed March 31, 2013.) 